Research article

\title{
Vitamin D pathway gene polymorphisms, diet, and risk of postmenopausal breast cancer: a nested case-control study
}

\author{
Marjorie L McCullough ${ }^{1}$, Victoria L Stevens ${ }^{1}$, William R Diver ${ }^{1}$, Heather S Feigelson ${ }^{1}$, \\ Carmen Rodriguez ${ }^{1}$, Robin M Bostick ${ }^{2}$, Michael J Thun ${ }^{1}$ and Eugenia E Calle ${ }^{1}$
}

\begin{abstract}
${ }^{1}$ Epidemiology and Surveillance Research, American Cancer Society, 1599 Clifton Road NE, Atlanta, GA 30329, USA
${ }^{2}$ Department of Epidemiology, Rollins School of Public Health, Emory University, 1518 Clifton Road NE, Atlanta, GA 30322, USA
\end{abstract}

Corresponding author: Marjorie L McCullough, marji.mccullough@cancer.org

Received: 3 Oct 2006 Revisions requested: 20 Nov 2006 Revisions received: 12 Dec 2006 Accepted: 23 Jan 2007 Published: 23 Jan 2007

Breast Cancer Research 2007, 9:R9 (doi:10.1186/bcr1642)

This article is online at: http://breast-cancer-research.com/content/9/1/R9

(c) 2007 McCullough et al:; licensee BioMed Central Ltd.

This is an open access article distributed under the terms of the Creative Commons Attribution License (http://creativecommons.org/licenses/by/2.0), which permits unrestricted use, distribution, and reproduction in any medium, provided the original work is properly cited.

\begin{abstract}
Introduction Vitamin D receptor (VDR) polymorphisms have been inconsistently associated with breast cancer risk. Whether risk is influenced by polymorphisms in other vitamin D metabolism genes and whether calcium or vitamin $D$ intake modifies risk by genotype have not been evaluated.

Methods We conducted a nested case-control study within the Cancer Prevention Study II Nutrition Cohort of associations between breast cancer and four VDR single-nucleotide polymorphisms (SNPs), Bsm1,Apa1,Taq1, and Fok1, a poly(A) microsatellite, and associated haplotypes (baTL and BAtS). We also examined one SNP in the 24-hydroxylase gene (CYP24A1) and two in the vitamin D-binding protein (group-specific component [GC]) gene. Participants completed a questionnaire on diet and medical history at baseline in 1992. This study includes 500 postmenopausal breast cancer cases and 500 controls matched by age, race/ethnicity, and date of blood collection.
\end{abstract}

Results Incident breast cancer was not associated with any genotype examined. However, women with the Bsm1 bb SNP who consumed greater than the median intake of total calcium ( $\geq 902 \mathrm{mg} /$ day) had lower odds of breast cancer compared to women with the $B b$ or $B B$ genotype and less than the median calcium intake (odds ratio $0.61,95 \%$ confidence interval 0.38 to $\left.0.96 ; p_{\text {interaction }}=0.01\right)$. Similar interactions were observed for Taq1 (T allele) and the poly (A) (LL) repeat.

Conclusion We found no overall association between selected vitamin $D$ pathway genes and postmenopausal breast cancer risk. However, certain VDR gene polymorphisms were associated with lower risk in women consuming high levels of calcium, suggesting that dietary factors may modify associations by VDR genotype.

\section{Introduction}

Vitamin D has been associated with a lower risk of several types of cancer, including breast cancer [1,2]. Its action is mediated through the vitamin $\mathrm{D}$ receptor (VDR), a nuclear transcription-regulating factor that signals the synthesis of proteins involved in bone mineral homeostasis and cell-cycle regulation [2]. The receptor is present in most cell types, including normal and neoplastic breast tissue [3]. Clinically, breast tumors with greater VDR expression relapse more slowly after first diagnosis [4].
The VDR gene contains several polymorphisms. Three singlenucleotide polymorphisms (SNPs) located near the 3' region have been examined in relation to breast cancer [2]. These polymorphisms, identified by their restriction endonuclease cleavage sites (Taq1,Bsm1, and Apa1), include an intronic $\mathrm{G} \rightarrow \mathrm{A}$ replacement $(B s m 1, \mathrm{rs} 1544410, \mathrm{G}=b)$, an intronic $\mathrm{C} \rightarrow \mathrm{A}$ replacement (Apa1, rs7975232, $\mathrm{C}=a$ ), and a $\mathrm{T} \rightarrow \mathrm{C}$ replacement in exon 9 (Taq1, rs731236, $\mathrm{C}=t)$, which result in a synonymous change at codon 352 . Although not functional, these SNPs are strongly linked with a poly $(A)$ microsatellite repeat in the $3^{\prime}$ untranslated region $[5,6]$ which may influence VDR mRNA stability. Five [7-11] of nine [7-15] studies reported higher breast cancer risk associated with the $B s m 1$ bb geno-

$\mathrm{Cl}=$ confidence interval; CPS $=$ Cancer Prevention Study; DBP = vitamin D-binding protein; FFQ = food frequency questionnaire; GC $=$ groupspecific component; OR = odds ratio; SNP = single-nucleotide polymorphism; VDR = vitamin $\mathrm{D}$ receptor. 
type. Other VDR 3' SNPs or haplotypes have been inconsistently related to breast cancer [16].

The presence of the Fok $1 f$ allele in the 5 ' promoter region of the VDR (rs2228570) results in production of a VDR protein that is three amino acids longer and less effective as a transcriptional activator [16]. The ff genotype was associated with a statistically significant 34\% higher breast cancer risk in the Nurses' Health Study [15]. Previous smaller studies of Fok1 and breast cancer risk were null $[7,13,17]$.

Gene-environment interactions may explain in part the inconsistencies in the association between VDR SNPs and breast cancer across studies. Dietary factors are known to impact the vitamin D endocrine system [18], and recent studies suggest that diet may also influence autocrine/paracrine vitamin D metabolism [19]. Few studies have examined interactions between dietary factors and VDR polymorphisms in relation to breast cancer risk. Furthermore, polymorphisms in other genes in the vitamin D metabolic pathway have not been examined in relation to breast cancer risk.

We examined several polymorphisms in the VDR gene, their associated haplotypes, and polymorphisms in the vitamin Dbinding (group-specific component [GC]) protein and $1,25(\mathrm{OH})_{2} \mathrm{D}$ degradation enzyme (CYP24A1) genes in relation to breast cancer risk in a nested case-control study of postmenopausal women enrolled in a large prospective cohort. Of particular a priori interest was whether calcium and vitamin $\mathrm{D}$ intakes modified associations by genotype.

\section{Materials and methods Study population}

Women in this analysis were participants in the Cancer Prevention Study (CPS) II Nutrition Cohort, a prospective study of cancer incidence among men and women from 21 states in the US, established by the American Cancer Society in 1992 [20]. At enrollment, 86,404 men and 97,788 women completed a 10-page, self-administered questionnaire on medical, dietary, reproductive, and lifestyle variables. Beginning in 1997, follow-up questionnaires were sent to cohort members every 2 years to update exposure information and to ascertain newly diagnosed tumors.

From June 1998 through June 2001, blood specimens were collected from 21,965 Nutrition Cohort postmenopausal women. Using blood samples, we identified 502 breast cancer cases who were cancer-free in 1992. For each case, we randomly selected one postmenopausal female control who had provided a blood sample and was cancer-free (except nonmelanoma skin cancer) at the time of the case's diagnosis [21]. Controls were individually matched to cases on birth date ( \pm 6 months), race/ethnicity (Caucasian, African-American, Hispanic, Asian, other/unknown), and date of blood collection ( \pm 6 months) using risk-set sampling. After excluding 2 cases with no match, 500 cases and 500 controls were available for analysis. All aspects of the CPS II cohort were approved by the Emory University (Atlanta, GA, USA) Institutional Review Board.

\section{Laboratory methods}

Genotyping was performed at Applied Biosystems (ABI, Foster City, CA, USA) by laboratory personnel blinded to casecontrol status; blinded quality control samples for $10 \%$ of participants were inserted to validate genotyping procedures. TaqMan (ABI, Foster City, CA, USA) was used to distinguish alleles of the VDR gene at restriction enzyme sites Fok1, Bsm 1, Apa1, and Taq1. A variable-length poly(A) sequence in the 3' untranslated region was assessed using methods previously described [6] and was classified as short $\left(S, A_{14}-A_{17}\right)$ or long ( $\left.L, A_{18}-A_{22}\right)$.

We also genotyped selected SNPs in vitamin D pathway genes that were relatively common and validated at study inception. Using TaqMan, we genotyped a T432G aspartate to glutamate SNP (rs7041) and an A436C threonine to lysine SNP (rs4588), both in exon 11 of the GC gene, which codes for the vitamin D-binding protein (DBP). We also measured a synonymous $A \rightarrow G$ SNP in exon 4 of the CYP24A1 gene (rs2296241), which encodes $24(\mathrm{OH})$ ase, which initiates degradation of $1,25(\mathrm{OH})_{2} \mathrm{D}$.

Concordance for quality control samples was 100\%. The overall success rate for genotyping assays was at least $95 \%$, except for Bsm1 (93\%). All SNPs were in Hardy-Weinberg equilibrium $(p>0.05)$.

\section{Dietary assessment}

Calcium, vitamin D, and dairy product intakes were measured in 1992 to 1993 [20] using a semi-quantitative 68-item food frequency questionnaire (FFQ), which is a modification of the brief 'Health Habits and History Questionnaire' developed by Block and colleagues [22]. Dietary and total nutrient intakes were estimated using the Diet Analysis System version 3.8a (Division of Cancer Prevention and Control, National Cancer Institute, Bethesda, MD, USA) [23]. Total calcium estimates (mg/day) included contributions from diet, individual calcium supplements (250, 500, 600, or $750 \mathrm{mg}$ per tablet), and multivitamin pills (estimated at $130 \mathrm{mg}$ per multivitamin pill). Vitamin $D$ values were added to the nutrient database using US Department of Agriculture sources [24]. Total intake of vitamin D (IU/day) was estimated from diet (fortified milk, cereals, and fish) and multivitamin usage (400 IU per pill). Nutrient estimates were adjusted for total energy using the residual method [25].

The FFQ was validated using four random 24-hour recalls collected throughout a 1-year period as the comparison measure among 441 Nutrition Cohort participants [26]. Median energyadjusted, attenuation-corrected Pearson validity correlations 
and $95 \%$ confidence intervals (Cls) among women were high for dietary calcium ( $r=0.66,95 \% \mathrm{Cl} 0.51$ to 0.76$)$ and for dairy products ( $r=0.63,95 \% \mathrm{Cl} 0.45$ to 0.77$)$.

\section{Statistical analyses}

We used a $\chi^{2}$ test to assess whether VDR, GC, and CYP24A1 genotype distributions were in Hardy-Weinberg equilibrium. Haplotypes of the VDR SNPs Bsm1,Apa1, and Taq1 and the poly $(A)$ repeat were estimated using the expectation-maximization algorithm implemented in the TAGSNPS program [27]. To account for matching, conditional logistic regression was used to examine the association between all SNPs and the VDR haplotypes and postmenopausal breast cancer risk. We adjusted for additional risk factors and confounders as noted below. The main analysis combined invasive $(n=393)$ and in situ $(n=107)$ breast tumors; sensitivity analyses excluding in situ cases showed similar findings; thus, all cases are presented.

Covariates included education, age at menopause and menarche, parity, age at first live birth, personal history of benign breast disease, family history of breast cancer in mother or sisters, postmenopausal hormone replacement therapy use, and body mass index. Adjustment for alcohol consumption did not change the effect estimates and was not included.

We examined whether dietary or total calcium or vitamin $D$ modified associations by genotype; interaction terms between genotypes and each dietary variable in continuous form were included in the conditional logistic regression models. Total energy intake was included in the models examining dietary interactions. Two-way interactions of the VDR haplotypes, Fok1, GC SNPs and the CYP24A1 SNP were examined. Sta- tistical interaction was evaluated using the Wald test; a $p$ value of less than 0.05 was considered statistically significant.

\section{Results}

Descriptive characteristics of participants in this study are presented in Table 1. Cases and controls had a median age of 62 years (range 43 to 75 years) at enrollment in 1992, and 99\% were Caucasian. None of the VDR genotypes or polymorphisms in the vitamin D-binding (GC) or CYP24A1 gene was significantly associated with overall postmenopausal breast cancer risk (Table 2). Heterozygote and homozygote variants for SNPs near the $3^{\prime}$ end of the VDR gene were combined because of similar odds ratios (ORs). Three VDR haplotypes were identified that explained more than $96 \%$ of the variance among these SNPs: baTL (45.2\%), BAtS (38.7\%), and bATL (12.3\%). Haplotype associations were similarly null: baTL OR $=0.89$ (95\% Cl 0.66 to 1.20$),$ BAtS OR $=1.24(95 \% \mathrm{Cl} 0.92$ to 1.66$)$, and $b A T L$ OR $=0.96(95 \% \mathrm{Cl} 0.69$ to 1.32$)$ for one or two copies vers

In analyses stratified by dietary factors, total calcium intake (but not vitamin D intake) modified the associations between polymorphisms near the $3^{\prime}$ end of the VDR and breast cancer risk (Table 3us none.). Compared to women with less than median total calcium intakes ( $<902 \mathrm{mg} /$ day) and the $B B$ or $B b$ $B s m 1$ genotype (reference group), women with calcium intakes of more than $902 \mathrm{mg} /$ day and the $b b$ genotype had a $39 \%$ lower risk of breast cancer $\left(p_{\text {interaction }}=0.01\right)$. Similar findings were observed for those with the Taq1 TT and the poly(A) LL tail. These interactions were similar and statistically significant for dietary calcium, and no effect modification was observed with dietary vitamin $\mathrm{D}$ or dairy product consumption. Diet did not modify the associations between GC or CYP24A1 gene polymorphisms and breast cancer risk (not

Table 1

Selected characteristics of breast cancer cases and controls

\begin{tabular}{|c|c|c|}
\hline Variable & Cases $n=500$ & Controls $n=500$ \\
\hline & \multicolumn{2}{|c|}{ Mean \pm standard deviation } \\
\hline Age at baseline (years) & $61.9 \pm 6.0$ & $61.9 \pm 6.0$ \\
\hline Age at menarche (years) & $12.7 \pm 1.4$ & $12.6 \pm 1.4$ \\
\hline Age at menopause (years) & $48.5 \pm 6.4$ & $48.1 \pm 6.0$ \\
\hline Paritya & $3.0 \pm 1.2$ & $3.3 \pm 1.5$ \\
\hline Race & \multicolumn{2}{|c|}{ Percentage } \\
\hline White & 98.6 & 98.8 \\
\hline Other or missing & 1.4 & 1.2 \\
\hline History of breast cyst & 38.8 & 30.0 \\
\hline Family history of breast cancer & 20.2 & 15.0 \\
\hline Ever pregnant & 88.8 & 90.0 \\
\hline
\end{tabular}

aMean number of children only among parous women. 
Table 2

Associations between SNPs in VDR, GC, and CYP24A1 genes and postmenopausal breast cancer risk ${ }^{\mathrm{a}}$

\begin{tabular}{|c|c|c|c|c|c|c|}
\hline \multirow[b]{2}{*}{ SNP } & \multicolumn{2}{|c|}{ Frequency } & \multicolumn{2}{|c|}{ Matched only } & \multicolumn{2}{|c|}{ Multivariate-adjustedb } \\
\hline & Cases & Controls (\%) & OR & $95 \% \mathrm{Cl}$ & OR & $95 \% \mathrm{Cl}$ \\
\hline \multicolumn{7}{|l|}{ VDR } \\
\hline \multicolumn{7}{|c|}{ Fok1 (rs2228570) } \\
\hline $\mathrm{FF}$ & 191 & $185(37.0)$ & 1.00 & - & 1.00 & - \\
\hline $\mathrm{Ff}$ & 207 & $227(45.4)$ & 0.89 & $(0.68-1.17)$ & 0.78 & $(0.58-1.05)$ \\
\hline $\mathrm{ff}$ & 77 & $68(13.6)$ & 1.11 & $(0.75-1.63)$ & 0.98 & $(0.65-1.50)$ \\
\hline \multicolumn{7}{|c|}{ Taq1 (rs731236) } \\
\hline tt or Tt & 336 & $312(62.4)$ & 1.00 & - & 1.00 & - \\
\hline TT & 158 & $180(36.0)$ & 0.82 & $(0.63-1.06)$ & 0.83 & $(0.62-1.12)$ \\
\hline \multicolumn{7}{|c|}{ Apa1 (rs7975232) } \\
\hline AA & 147 & $129(25.8)$ & 1.00 & - & 1.00 & - \\
\hline Aa or aa & 341 & $348(69.6)$ & 0.87 & $(0.65-1.15)$ & 0.87 & $(0.64-1.18)$ \\
\hline \multicolumn{7}{|c|}{ Bsm1 (rs1544410) } \\
\hline $\mathrm{BB}$ or $\mathrm{Bb}$ & 321 & $290(58.0)$ & 1.00 & - & 1.00 & - \\
\hline $\mathrm{bb}$ & 151 & $170(34.0)$ & 0.81 & $(0.61-1.06)$ & 0.84 & $(0.62-1.15)$ \\
\hline \multicolumn{7}{|l|}{ Poly $(A)$ tail } \\
\hline SS or SL & 328 & $304(60.8)$ & 1.00 & - & 1.00 & - \\
\hline LL & 158 & $177(35.4)$ & 0.83 & $(0.63-1.08)$ & 0.83 & $(0.61-1.12)$ \\
\hline \multicolumn{7}{|c|}{ GC protein (rs4588) } \\
\hline $\mathrm{C} / \mathrm{C}$ & 240 & $246(51.7)$ & 1.00 & - & 1.00 & - \\
\hline $\mathrm{A} / \mathrm{C}$ & 202 & $186(39.1)$ & 1.11 & $(0.84-1.45)$ & 1.11 & $(0.82-1.48)$ \\
\hline $\mathrm{A} / \mathrm{A}$ & 48 & $44(9.2)$ & 1.13 & $(0.73-1.76)$ & 1.30 & $(0.80-2.13)$ \\
\hline \multicolumn{7}{|c|}{ GC protein (rs7041) } \\
\hline $\mathrm{G} / \mathrm{G}$ & 154 & $149(30.4)$ & 1.00 & - & 1.00 & - \\
\hline $\mathrm{G} / \mathrm{T}$ & 237 & $235(48.0)$ & 0.98 & $(0.72-1.33)$ & 0.94 & $(0.67-1.31)$ \\
\hline $\mathrm{T} / \mathrm{T}$ & 103 & $106(21.6)$ & 0.94 & $(0.66-1.33)$ & 0.96 & $(0.65-1.41)$ \\
\hline \multicolumn{7}{|c|}{ CYP24A1 (rs2296241) } \\
\hline $\mathrm{A} / \mathrm{A}$ & 141 & $139(28.4)$ & 1.00 & - & 1.00 & - \\
\hline $\mathrm{A} / \mathrm{G}$ & 254 & $253(51.6)$ & 0.99 & $(0.74-1.31)$ & 1.03 & $(0.75-1.41)$ \\
\hline $\mathrm{G} / \mathrm{G}$ & 99 & $98(20.0)$ & 1.00 & $(0.70-1.43)$ & 1.05 & $(0.71-1.56)$ \\
\hline
\end{tabular}

aAll models contain a variable for unknown SNP genotype which is not presented. bModels are adjusted for body mass index, history of breast cyst, hormone replacement therapy use, family history of breast cancer, education, parity and age at first birth combined, age at menarche, and age at menopause. Cl, confidence interval; GC, group-specific component; OR, odds ratio; SNP, single-nucleotide polymorphism; VDR, vitamin D receptor.

shown). We also observed no statistically significant effect modification in analyses stratified by median UV index for the state of residence as a proxy for cutaneous production of vitamin D. In addition, we observed no significant interactions between any two-way combination of VDR haplotypes, Fok1, or CYP24A1 or GC genotypes or in specific combinations of Fok1 and poly(A) genotypes.

\section{Discussion}

None of the genotypes or haplotypes examined from the vitamin D pathway was associated with postmenopausal breast cancer risk in all women. However, women with a calcium intake higher than the median were at lower breast cancer risk if they had the VDR Bsm1 $b b$, Taq1 TT, or the poly(A) long repeat (LL) genotype. Among women with a calcium intake 
VDR genotype and postmenopausal breast cancer risk stratified by total calcium and vitamin D intakes

\begin{tabular}{|c|c|c|c|c|c|c|c|c|}
\hline \multirow[b]{3}{*}{ SNP } & \multicolumn{4}{|c|}{ Total calcium (mg/day) } & \multicolumn{4}{|c|}{ Total vitamin D (IU/day) } \\
\hline & \multicolumn{2}{|c|}{$<902$} & \multicolumn{2}{|c|}{$902+$} & \multicolumn{2}{|c|}{$<222$} & \multicolumn{2}{|c|}{$222+$} \\
\hline & OR & $95 \% \mathrm{Cl}$ & OR & $95 \% \mathrm{Cl}$ & OR & $95 \% \mathrm{Cl}$ & OR & $95 \% \mathrm{Cl}$ \\
\hline \multicolumn{9}{|l|}{ Fok 1} \\
\hline $\mathrm{FF}$ & 1.00 & - & 0.91 & $(0.56-1.47)$ & 1.00 & - & 0.89 & $(0.55-1.45)$ \\
\hline $\mathrm{Ff}$ & 0.79 & $(0.50-1.25)$ & 0.80 & $(0.50-1.26)$ & 0.72 & $(0.45-1.14)$ & 0.88 & $(0.56-1.39)$ \\
\hline \multirow[t]{2}{*}{$\mathrm{ff}$} & 1.08 & $(0.56-2.09)$ & 0.63 & $(0.32-1.24)$ & 1.03 & $(0.53-1.99)$ & 0.68 & $(0.36-1.29)$ \\
\hline & \multicolumn{4}{|c|}{$p_{\text {interaction }}=0.34^{b}$} & \multicolumn{4}{|c|}{$p_{\text {interaction }}=0.18$} \\
\hline \multicolumn{9}{|l|}{ Taq1 } \\
\hline tt or $\mathrm{Tt}$ & 1.00 & - & 1.16 & $(0.81-1.65)$ & 1.00 & - & 1.02 & $(0.70-1.49)$ \\
\hline \multirow[t]{2}{*}{$\mathrm{TT}$} & 1.24 & $(0.79-1.94)$ & 0.64 & $(0.41-0.99)$ & 0.88 & $(0.56-1.38)$ & 0.77 & $(0.50-1.21)$ \\
\hline & \multicolumn{4}{|c|}{$p_{\text {interaction }}=0.01$} & \multicolumn{4}{|c|}{$p_{\text {interaction }}=0.36$} \\
\hline \multicolumn{9}{|l|}{ Apa1 } \\
\hline AA & 1.00 & - & 0.86 & $(0.49-1.50)$ & 1.00 & - & 0.86 & $(0.48-1.53)$ \\
\hline \multirow[t]{2}{*}{ Aa or aa } & 0.86 & $(0.53-1.38)$ & 0.74 & $(0.47-1.17)$ & 0.77 & $(0.49-1.20)$ & 0.82 & $(0.52-1.31)$ \\
\hline & \multicolumn{4}{|c|}{$p_{\text {interaction }}=0.77$} & \multicolumn{4}{|c|}{$p_{\text {interaction }}=0.47$} \\
\hline \multicolumn{9}{|l|}{ Bsm1 } \\
\hline $\mathrm{BB}$ or $\mathrm{Bb}$ & 1.00 & - & 1.05 & $(0.71-1.55)$ & 1.00 & - & 0.90 & $(0.60-1.35)$ \\
\hline \multirow[t]{2}{*}{$\mathrm{bb}$} & 1.20 & $(0.73-1.95)$ & 0.61 & $(0.38-0.96)$ & 0.72 & $(0.44-1.18)$ & 0.78 & $(0.49-1.26)$ \\
\hline & \multicolumn{4}{|c|}{$p_{\text {interaction }}=0.01$} & \multicolumn{4}{|c|}{$p_{\text {interaction }}=0.90$} \\
\hline \multicolumn{9}{|l|}{ Poly $(\mathrm{A})$ tail } \\
\hline SS or SL & 1.00 & - & 1.16 & $(0.81-1.67)$ & 1.00 & - & 0.96 & $(0.66-1.41)$ \\
\hline \multirow[t]{2}{*}{$\mathrm{LL}$} & 1.18 & $(0.74-1.87)$ & 0.66 & $(0.42-1.04)$ & 0.79 & $(0.50-1.26)$ & 0.77 & $(0.49-1.21)$ \\
\hline & \multicolumn{4}{|c|}{$p_{\text {interaction }}=0.02$} & \multicolumn{4}{|c|}{$p_{\text {interaction }}=0.72$} \\
\hline
\end{tabular}

aMultivariate adjusted models contain the SNP, dietary exposure, and interaction term and adjust for body mass index, history of breast cyst, hormone replacement therapy use, family history of breast cancer, education, parity and age at first birth combined, age at menarche, age at menopause, and total energy intake. bInteraction terms were created using continuous form of dietary variables. Cl, confidence interval; OR, odds ratio; SNP, single-nucleotide polymorphism; VDR, vitamin D receptor.

lower than the median, these VDR genotypes were not associated with lower breast cancer risk.

The lack of association between the Bsm 1 bb genotype or associated polymorphisms in the $3^{\prime}$ region and breast cancer risk is in contrast to findings in five studies that reported increased risk of breast cancer, mostly among Caucasian women with the $b b$ genotype [7-11]. Four other studies, plus ours, have not replicated this association [12-15]; two of these were in Hispanic [13] and Taiwanese [14] women. Other SNPs in the baT haplotype allele likewise have been inconsistently related to breast cancer risk [16]. It is unclear whether chance or underlying differences in the populations studied explain these inconsistencies. It is conceivable that differences in background risk factor profiles (menopausal status, reproductive factors, obesity, or dietary intake) contribute to these variations. Most of these studies included both pre- and postmenopausal cases; in the one study that presented results stratified by menopausal status [15], results for the $B s m / B B$ versus the $b b$ allele were similar for premenopausal $(\mathrm{OR}=0.92)$ and postmenopausal $(\mathrm{OR}=0.94)$ women.

In our study, dietary calcium intake, but not vitamin D intake, significantly modified the association between VDR SNPs near the $3^{\prime}$ end of the gene and breast cancer risk. Both nutrients have direct effects on cell proliferation and differentiation of several cancer cell lines in vitro $[28,29]$. In a rodent model, calcium reduces fat-induced cell proliferation by maintaining intracellular calcium concentrations [30]. It is plausible that polymorphisms in the VDR gene could modify the effects of exposures such as vitamin $D$ or calcium on breast cancer risk, although the specific mechanisms in humans are unknown. Although vitamin D intake did not modify risk in our analysis, we did not measure plasma $25(\mathrm{OH}) \mathrm{D}$, an integrated 
measure of vitamin D status from diet and UVB synthesis. Higher circulating levels of the storage form of vitamin $D$ $(25(\mathrm{OH}) \mathrm{D})$ may lower breast cancer risk $[9,31]$, potentially by providing substrate for breast tissue-specific synthesis of $1,25(\mathrm{OH})_{2} \mathrm{D}$ [3]. In one case-control study in the UK, women with low plasma 25(OH)D levels and the Bsm/ bb VDR genotype had a 6.8-fold higher risk of breast cancer than individuals with higher $25(\mathrm{OH}) \mathrm{D}$ levels and the $B B$ or $B b$ genotype [9]. Thus, calcium or related nutrients may influence tissue-specific vitamin D metabolism in ways that are as yet unclear, possibly varying by VDR genotype. The interactions we observed may also be due to chance and should be replicated.

Our null findings for the Fok1 ff SNP and breast cancer risk do not replicate the positive association observed in the Nurses' Health Study [15] but do agree with those of three smaller studies [7,13,17], nor did we replicate previously reported potential interactions between different VDR polymorphisms observed by others [8,15]. Guy and colleagues [8] reported an approximately two-fold increase in risk among women with the FFLL or FfLL genotypes versus other combinations; among patients with metastases, the risk was three-fold greater. The mix of grade, lymph node involvement, or metastases in cases studied may also contribute to variability in findings across studies.

We observed no association with two non-synonymous polymorphisms in the GC gene (codes for DBP) or one in CYP24A1 and postmenopausal breast cancer. The polymorphic DBP facilitates vitamin D actions, and DBP alleles differ in their affinity for $1,25(\mathrm{OH})_{2} \mathrm{D}$ [32]. The CYP24A1 gene codes for $24(\mathrm{OH})$ ase, which degrades $1,25(\mathrm{OH})_{2} \mathrm{D}$. The potential for the SNPs we examined to alter DBP or CYP24A1 function is possible but has not been studied. Some studies have suggested a relationship of these SNPs with other outcomes, including asthma, glucose tolerance, and bone mineral density [33-35]. We are not aware of any studies that examined these SNPs in relation to breast cancer.

Limitations of this analysis include the use of a single assessment of diet, on average 6 years before diagnosis of breast cancer, which may have led to misclassification of dietary intake. We did not measure blood levels of $25(\mathrm{OH}) \mathrm{D}$ to assess vitamin D status. However, our FFQ was validated [26] and diet was assessed before cancer diagnosis. Larger case numbers would have provided greater statistical power to examine gene-gene and gene-diet interactions; however, this study is among the largest published to date for postmenopausal breast cancer.

\section{Conclusion}

Our research does not support an independent association between selected polymorphisms in the VDR, GC, or CYP24A1 genes and postmenopausal breast cancer risk among US Caucasian women. However, calcium intake appeared to modify the association of VDR SNPs with breast cancer risk. More research is needed to determine whether environmental factors, particularly diet, influence cancer risk by vitamin $\mathrm{D}$ pathway genotype.

\section{Competing interests}

The authors declare that they have no competing interests.

\section{Authors' contributions}

MLM conceived the study and drafted the manuscript. VLS, HSF, EEC, and RMB made substantial contributions to the conception and design of the study. MJT, CR and EEC made substantial contributions to the acquisition and interpretation of data. WRD conducted the statistical analyses. All authors were involved in revising the manuscript critically for important intellectual content. All authors read and approved the final manuscript.

\section{References}

1. Giovannucci E: The epidemiology of vitamin D and cancer incidence and mortality: a review (United States). Cancer Causes Control 2005, 16:83-95.

2. Colston K, Welsh J: Vitamin D and breast cancer. In Vitamin $D$ Volume II. Edited by: Feldman D, Glorieux FH, Pike JW. Stanford, CA: Elsevier Academic Press; 2005:1663-1677.

3. Townsend K, Banwell CM, Guy M, Colston KW, Mansi JL, Stewart PM, Campbell MJ, Hewison M: Autocrine metabolism of vitamin $\mathrm{D}$ in normal and malignant breast tissue. Clin Cancer Res 2005, 11:3579-3586.

4. Colston KW, Berger U, Coombes RC: Possible role for vitamin $\mathrm{D}$ in controlling breast cancer cell proliferation. Lancet 1989, 1:188-191.

5. Ingles SA, Haile RW, Henderson BE, Kolonel LN, Nakaichi G, Shi C, Yu MC, Ross RK, Coetzee GA: Strength of linkage disequilibrium between two vitamin $D$ receptor markers in five ethnic groups: implications for association studies. Cancer Epidemiol Biomarkers Prev 1997, 6:93-98.

6. Slattery ML, Yakumo K, Hoffman M, Neuhausen S: Variants of the VDR gene and risk of colon cancer (United States). Cancer Causes Control 2001, 12:359-364.

7. Bretherton-Watt D, Given-Wilson R, Mansi JL, Thomas V, Carter N, Colston KW: Vitamin D receptor gene polymorphisms are associated with breast cancer risk in a UK Caucasian population. Br J Cancer 2001, 85:171-175.

8. Guy M, Lowe LC, Bretherton-Watt D, Mansi JL, Peckitt C, Bliss J, Wilson RG, Thomas V, Colston KW: Vitamin D receptor gene polymorphisms and breast cancer risk. Clin Cancer Res 2004, 10:5472-5481.

9. Lowe LC, Guy M, Mansi JL, Peckitt C, Bliss J, Wilson RG, Colston $\mathrm{KW}$ : Plasma 25-hydroxy vitamin D concentrations, vitamin D receptor genotype and breast cancer risk in a UK Caucasian population. Eur J Cancer 2005, 41:1164-1169.

10. Yamagata Z, Zhang Y, Asaka A: Association of breast cancer with vitamin $\mathrm{D}$ receptor gene polymorphism (abstract). $\mathrm{Am} J$ Hum Genet 1997, 61:A388.

11. Ruggiero M, Pacini S, Aterini S, Fallai C, Ruggiero C, Pacini P: Vitamin $D$ receptor gene polymorphism is associated with metastatic breast cancer. Oncol Res 1998, 10:43-46.

12. Buyru N, Tezol A, Yosunkaya-Fenerci E, Dalay N: Vitamin D receptor gene polymorphisms in breast cancer. Exp Mol Med 2003, 35:550-555.

13. Ingles SA, Garcia DG, Wang W, Nieters A, Henderson BE, Kolonel LN, Haile RW, Coetzee GA: Vitamin D receptor genotype and breast cancer in Latinas (United States). Cancer Causes Control 2000, 11:25-30.

14. Hou MF, Tien YC, Lin GT, Chen CJ, Liu CS, Lin SY, Huang TJ: Association of vitamin $D$ receptor gene polymorphism with sporadic breast cancer in Taiwanese patients. Breast Cancer Res Treat 2002, 74:1-7. 
15. Chen WY, Bertone-Johnson ER, Hunter DJ, Willett WC, Hankinson SE: Associations between polymorphisms in the vitamin D receptor and breast cancer risk. Cancer Epidemiol Biomarkers Prev 2005, 14:2335-2339.

16. Uitterlinden AG, Fang Y, van Meurs JBJ, Pols HAP: Genetic vitamin D receptor polymorphisms and risk of disease. In Vitamin $D$ Volume II. Edited by: Feldman D, Glorieux FH, Pike JW. Stanford, CA: Elsevier Academic Press; 2005.

17. Curran JE, Vaughan T, Lea RA, Weinstein SR, Morrison NA, Griffiths LR: Association of a vitamin D receptor polymorphism with sporadic breast cancer development. Int J Cancer 1999, 83:723-726.

18. Holick M: Vitamin D. In Modern Nutrition in Health and Disease 9th edition. Edited by: Shils ME, Olson JA, Shike M, Ross AC. Philadelphia, PA: Lippincott Williams \& Wilkins; 1999.

19. Cross HS, Kallay E, Lechner D, Gerdenitsch W, Adlercreutz H, Armbrecht HJ: Phystoestrogens and vitamin D metabolism: a new concept for the prevention and therapy of colorectal, prostate, and mammary carcinomas. J Nutr 2004, 134:1207S-1212S.

20. Calle EE Rodriguez C Jacobs EJ Almon ML Chao A McCullough ML, Feigelson HS, Thun MJ: The American Cancer Society Cancer Prevention Study II Nutrition Cohort: rationale, study design, and baseline characteristics. Cancer 2002, 94:2490-2501.

21. Rothman KJ, Greenland S: Modern Epidemiology 2nd edition. Philadelphia, PA: Lippincott Williams \& Wilkins; 1998

22. Block G, Hartman AM, Naughton D: A reduced dietary questionnaire: development and validation. Epidemiology 1990, 1:58-64.

23. Block G, Coyl L, Smucker R, Harlan LC: Health Habits and History Questionnaire: diet history and other risk factors. [Personal computer system documentation]. Bethesda, MD: National Cancer Institute Division of Cancer Prevention and Control, National Institutes of Health; 1989.

24. US Department of Agriculture: Provisional Table On Vitamin D Content Of Foods [http://www.nal.usda.gov/fnic/foodcomp/ Data/Other/vit d99.pdf]

25. Willett W, Stampfer MJ: Total energy intake: implications for epidemiologic analyses. Am J Epidemiol 1986, 124:17-27.

26. Flagg EW, Coates RJ, Calle EE, Potischman N, Thun MJ: Validation of the American Cancer Society Cancer Prevention Study II Nutrition Survey Cohort Food Frequency Questionnaire. Epidemiology 2000, 11:462-468.

27. Stram DO, Leigh Pearce C, Bretsky $P$, Freedman M, Hirschhorn IN, Altshuler D, Kolonel LN, Henderson BE, Thomas DC: Modeling and E-M estimation of haplotype-specific relative risks from genotype data for a case-control study of unrelated individuals. Hum Hered 2003, 55:179-190.

28. Lipkin M, Newmark HL: Vitamin D, calcium, and prevention of breast cancer: a review. J Am Coll Nutr 1999, 18:392S-397S.

29. Martinez ME, Willett WC: Calcium, vitamin D and colorectal cancer: a review of the epidemiologic evidence. Cancer Epidemiol Biomarkers Prev 1998, 7:163-168.

30. Jacobson EA, James KA, Newmark HL, Carroll KK: Effects of dietary fat, calcium, and vitamin $D$ on growth and mammary tumorigenesis induced by 7,12-dimethylbenz(a)anthracene in female Sprague-Dawley rats. Cancer Res 1989, 49:6300-6303.

31. Bertone-Johnson ER, Chen WY, Holick MF, Hollis BW, Colditz GA, Willett WC, Hankinson SE: Plasma 25-hydroxyvitamin D and 1,25-dihydroxyvitamin $D$ and risk of breast cancer. Cancer Epidemiol Biomarkers Prev 2005, 14:1991-1997.

32. Pani MA, Regulla K, Segni M, Hofmann S, Hufner M, Pasquino AM, Usadel $\mathrm{KH}$, Badenhoop $\mathrm{K}$ : A polymorphism within the vitamin D-binding protein gene is associated with Graves' disease but not with Hashimoto's thyroiditis. J Clin Endocrinol Metab 2002, 87:2564-2567.

33. Ezura $Y$, Nakajima $T$, Kajita M, Ishida R, Inoue $S$, Yoshida H, Suzuki T, Shiraki M, Hosoi T, Orimo H, Emi M, et al:: Association of molecular variants, haplotypes, and linkage disequilibrium within the human vitamin D-binding protein (DBP) gene with postmenopausal bone mineral density. J Bone Miner Res 2003, 18:1642-1649.

34. Wjst M, Altmuller J, Faus-Kessler T, Braig C, Bahnweg M, Andre E: Asthma families show transmission disequilibrium of gene variants in the vitamin $D$ metabolism and signalling pathway. Respir Res 2006, 7:60.

35. Hirai M, Suzuki S, Hinokio Y, Hirai A, Chiba M, Akai H, Suzuki C, Toyota T: Variations in vitamin D-binding protein (group-specific component protein) are associated with fasting plasma insulin levels in Japanese with normal glucose tolerance. $J$ Clin Endocrinol Metab 2000, 85:1951-1953. 